McCrumb et al. (1962) also showed that very small doses of vaccine virus, as assayed in tissue culture, would infect human subjects. Rey et al. (1965) obtained $95 \%$ sero-conversion rate with $100 \mathrm{TCID}_{50}$ of Schwartz further-attenuated vaccine, and Cooper et al. (1966) quote a personal communication from Dr. Schwartz indicating that as little as $10 \mathrm{TCID}_{50}$ of this vaccine, given by syringe and needle, will infect.

Hendrickse et al. (1966) noted that doses of approximately $30 \mathrm{TCID}_{50}$ of Leningrad 16 measles vaccine, as titrated in Hep- 2 cells, produced a $78 \%$ sero-conversion rate when given by syringe and needle to a small group of children. The same group of workers reported (Hendrickse et al., 1967) promising results when small doses of further-attenuated vaccine were given by Dermojet ; the disadvantage of this apparatus is that only about $0.07 \mathrm{ml}$. is delivered, and sometimes it is obvious that a substantial proportion of the dose remains on the skin. A similar observation was made by Calafiore et al. (1968), who showed that the efficacy of Schwartz vaccine was dependent not only on the dose administered in terms of $\mathrm{TCID}_{50}$ content but also on the volume of fluid in which the virus was injected. These workers suggested that small infective doses might be satisfactory when given in a relatively large volume, but that until this had been demonstrated $1,000 \mathrm{TCID}_{50}$ should be retained as the standard dose.

Markham (1962) also noted that low doses of measles vaccine would produce good sero-conversion rates, and felt that the main reason for having a $1,000 \mathrm{TCID}_{50}$ dose as standard was the relative instability of the fluid vaccine.

The stability of the reconstituted vaccine depends, however, not only on the nature of the virus itself but also on the stabilizers incorporated in the vaccine preparation during manufacture. The present work shows that, at least with the particular vaccine used, stability of the virus suspension, when used in low dosage, need not be a problem. Good sero-conversion rates were obtained with a dose of $200 \mathrm{TCID}_{50}$ under field conditions, with the vaccine injected subcutaneously in a volume of $0.5 \mathrm{ml}$.

While it may be desirable to confirm these results with other vaccine preparations, it would seem that the way is open for a considerable reduction in the cost per dose of measles vaccine, especially when used on a scale large enough to justify the use of multidose containers.

We wish to thank the Permanent Secretary, Ministry of Health, Kwara State, for permission to carry out this study ; the management and medical staff at Bacita Sugar Estate for their co-operation, the use of their clinic facilities, and kind hospitality ; the Wellcome Research Laboratories for supplies of vaccine; Dr. M. Gurney, Alhaji S. Aderinto, Mr. A. Akinkunmi, and Mr. G. Coker, for their active participation in the trial; and Dr. M. Grisby (U.S.A.I.D.) for the loan of a Ped-O-Jet needleless injector.

\section{REFERENCES} Calafiore, D. C., Nader, P. R., Lepow, M. L., Nankervis, G. A., Casey,
H., and Warren, R. J. (1968). Amer. Y. Epidem., 87, 247. Cooper, C., Morley, D. C., Weeks, M. C., and Beale, A. J. (1966). Lancet, 1, 1076.

Hendrickse, R. G., Montefiore, D., Sherman, P., and Peradze, T. (1966). Brit. med. F., 1, 779 .

Hendrickse, R. G., Montefiore, D., and Sherman, P. (1967). Nigerian Med. Ass. (Western Branch) News Bull., 1, pp. 9-10.

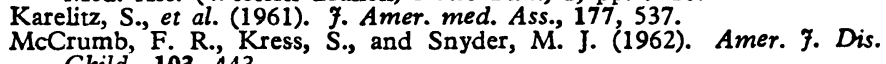
Child., 103, 443.

Markham, F. S. (1962). Amer. F. Dis. Child., 103, 437.

Rey, M., Baylet, R., Cantrelle, P., Dauchy, S., Diop Mar., I., and Guévin, M.' (1965). Bull. Soc. méd. Afr. noire Langue franç., 10, 392.

\title{
Dermatitis Herpetiformis in Two Patients with Idiopathic Steatorrhoea (Adult Coeliac Disease)
}

\author{
N. G. FRASER,* M.B., M.R.C.P.ED. ; ANNE FERGUSON, $†$ M.B., B.SC., M.R.C.P., M.R.C.P.GLASG. \\ D. MURRAY $\ddagger$ M.B., B.SC.
}

Brit. med.F., 1968, 4, 30-31

\begin{abstract}
Cummary: Two patients who had had idiopathic steatorrhoea for several years developed typical eruptions of dermatitis herpetiformis. In each case the rash responded to treatment with dapsone.

It is more usual for the rash to precede the enteropathy when the two occur together, but the association between coeliac disease and dermatitis herpetiformis is not yet clear.
\end{abstract}

\section{Introduction}

Dermatitis herpetiformis, one of the blistering group of skin diseases, is associated with histological abnormalities of the small intestine in about $70 \%$ of patients (Marks et al., 1966 ; Fraser et al., 1967 ; Fry et al., 1967 ; van Tongeren et al., 1967 ;

\footnotetext{
- Senior Registrar, University Department of Dermatology, Western Infirmary, Glasgow W.1.

† Lecturer, University Department of Medicine, Glasgow Royal Infirm-

₹ Lecturer, University Department of Pathology, Glasgow Royal Infirmary.
}

Marks et al., 1968). The malabsorption state which may accompany this intestinal abnormality is generally mild, but troublesome diarrhoea, weight loss, and anaemia can occur. Thus upset in intestinal structure and function has previously been shown only in patients who had already developed the rash of dermatitis herpetiformis, though a history of diarrhoea antedating the rash has been reported in some patients (Fraser et al., 1967 ; Marks et al., 1968).

In the following two cases diagnosed initially as idiopathic steatorrhoea the typical eruption of dermatitis herpetiformis developed after several years.

\section{Case 1}

This patient was first admitted to Glasgow Royal Infirmary in December 1956, at the age of 52 years, for investigation of anaemia. The presenting symptoms were tiredness and exertional dyspnoea. There were no symptoms referable to the gastrointestinal tract. Treatment with folic acid had been given before admission. 
Examination revealed a thin, slightly pale woman, height $5 \mathrm{ft} .6$ in. $(167.6 \mathrm{~cm}$.), weight $126 \mathrm{lb}$. (57.2 kg.). Other systems were normal.

Investigations.-Haemoglobin $79 \%$; R.B.C. 3,320,000/cu. mm. ; W.B.C. $8,400 /$ cu. mm.; reticulocytes $1.2 \%$; platelets $300,000-$ $500,000 / \mathrm{cu}$. mm. ; film-anisocytosis with slight macrocytosis; sternal marrow-normoblastic erythropoiesis. Serum vitamin $\mathbf{B}_{12}$ level $50 \mu \mathrm{g} . / \mathrm{ml}$. Test meal-free $\mathrm{HCl}$ after histamine. Serum albumin 3.6 g. $/ 100 \mathrm{ml}$. Glucose tolerance test-flat curve. Fat balance- $89 \%$ absorption. Barium meal and follow-through negative.

Treatment with $1,000 \mu \mathrm{g}$. of vitamin $B_{12}$ was given intramuscularly with no significant haematological response. In view of the high faecal fat a diagnosis of idiopathic steatorrhoea was made, a gluten-free diet being started. This diet was discontinued after three months.

In June 1958 fat malabsorption was confirmed ( ${ }^{131}$ I studies). The anaemia was still present ( $\mathrm{Hb} 79 \%$ ), and so the gluten-free diet was restarted and folic acid $10 \mathrm{mg}$. b.d. by mouth was prescribed. The diet was again discontinued in 1962 at the patient's request.

In June 1964 she was referred to the skin department with an excoriated erythemato-papular itching eruption of the upper arms and knees. No diagnosis was made, and the skin settled on Betnovate (betamethasone 17-valerate) ointment. The rash recurred several months later, however, and continued to be troublesome until finally, in March 1967, she was admitted for investigation. The skin eruption-excoriated papules and papulovesicles on elbows, knees, buttocks, and scalp-was consistent with dermatitis herpetiformis, and this was confirmed histologically. Jejunal biopsy revealed partial villous atrophy and the five-day faecal fat was $10.9 \mathrm{~g}$./day. Xylose excretion was $1.3 \mathrm{~g}$./volume after a $5 \mathrm{-g}$ dose. Serum IgM was low at $38 \mathrm{mg} . / 100 \mathrm{ml}$. Full blood investigations gave normal results, the patient being under treatment from the blood clinic with folic acid $10 \mathrm{mg}$. b.d. by mouth, $1,000 \mu \mathrm{g}$. vitamin $B_{12}$ intramuscularly every four weeks, and intermittent oral iron therapy. Dapsone therapy was started, and the rash has been well controlled on 50-100 mg. daily.

\section{Case 2}

This patient was first admitted to Glasgow Royal Infirmary in October 1965, at the age of 57 years, with a 16-month history of weight loss (40 lb.; $18.1 \mathrm{~kg}$.) and a seven-month history of diarrhoea (up to 12 stools daily). Examination revealed a low-grade pyrexia, evidence of weight less, a red smooth tongue, angular stomatitis, and marked palmar erythema. B.P. was $100 / 70 \mathrm{~mm}$. Hg. The abdomen was full but no masses were palpable.

Investigations.-Haemoglobin 9 g. $/ 100 \mathrm{ml}$.; packed cell volume $29 \%$; mean corpuscular haemoglobin concentration $31 \%$; erythrocyte sedimentation rate (Westergren) $60 \mathrm{~mm}$. in one hour; filmanisocytosis, target cells, macrocytosis, hypersegmented polymorphs; marrow examination-megaloblastic change, stainable iron present. Serum vitamin $\mathrm{B}_{12}<10 \mu \mathrm{g} . / 100 \mathrm{ml}$. Schilling test- $0.5 \%$ dose excreted in urine in 24 hours. Figlu test positive. Serum iron $40 \mu \mathrm{g} . / 100 \mathrm{ml}$., total iron-binding capacity $204 \mu \mathrm{g} . / 100 \mathrm{ml}$., saturation $20 \%$. Serum potassium $3.3 \mathrm{mEq} / 1$; serum albumin $3.1 \mathrm{~g} . /$ $100 \mathrm{ml}$. ; serum calcium $2.5 \mathrm{mEq} / 1$. ; inorganic phosphate $2.3 \mathrm{mg} . /$ $100 \mathrm{ml}$. ; alkaline phosphatase 19 K.A. units $/ 100 \mathrm{ml}$. Liver function tests normal. Tubular reabsorption of phosphate $97 \%$. $X$-ray examination of spine-osteoporosis. Xylose excretion $0.77 \mathrm{~g} . \%$ volume after a 5 -g. dose. Small-bowel $x$-ray examination-flocculation of barium in small intestine. Jejunal biopsy-partial villous atrophy. Disaccharidase results are shown in the Table. The diagnosis of adult coeliac disease was made and she was treated initially with vitamin $B_{12}$, folic acid, intramuscular iron, Parentrovite, vitamin $\mathrm{D}$ and calcium, and gluten-free diet.

Investigations in Case 2 Before and Three Years After Treatment With

\begin{tabular}{|c|c|c|c|}
\hline & & Before Gluten-free Diet & After Gluten-free Diet \\
\hline $\begin{array}{ll}\text { Weight } & . \\
\text { Intestinal mucosa } \\
\text { Maltase* } & . \\
\text { Lactase }^{*} & \quad . \\
\text { Sucrase* } & \quad .\end{array}$ & $\begin{array}{ll}\because & \\
\because & \\
\because & \\
\therefore & \end{array}$ & $\begin{array}{c}105 \mathrm{lb} \text {. }(47.6 \mathrm{~kg} .) \\
\text { Partial villous atrophy } \\
6.1 \\
0.2 \\
1.7\end{array}$ & $\begin{array}{c}147 \mathrm{lb} .(66.7 \mathrm{~kg} \text {.) } \\
\text { Partial villous atrophy } \\
18.5 \\
0.3 \\
5.4\end{array}$ \\
\hline
\end{tabular}

- Units of activity ( $\mu$ moles st bstrate hydrolysed per minute) per gramme of tissue wet weight (lower limits of normal-maltase 13 units, lactase 1.4 units, tissue wet weight
One year later her weight had increased by $42 \mathrm{lb}$. (19 kg.) and treatment was continued with a gluten-free diet, folic acid $10 \mathrm{mg}$. b.d., ferrous sulphate 0.2 g. t.i.d., and vitamin $B_{12} 1,000 \mu$ g monthly.

In February 1968 she noticed an itching, blistering eruption affecting mainly the scalp, elbows, abdomen, and back of knees. Skin biopsy confirmed the clinical diagnosis of dermatitis herpitiformis. Her only other complaint was of occasional flatulence and abdominal distension after meals. Repeat jejunal biopsy again showed partial villous atrophy, but the disaccharidase activity (except lactase) was normal (see Table). Full blood examination was normal. A lactose tolerance test with $100 \mathrm{~g}$. of lactose reproduced the patient's symptoms and the maximum blood sugar rise was only $14 \mathrm{mg} . / 100 \mathrm{ml}$. A lactose-free diet was added to the glutenfree diet. The skin eruption was satisfactorily controlled on $50 \mathrm{mg}$. of dapsone daily.

\section{Discussion}

The relation between the skin and small intestine in dermatitis herpetiformis is uncertain. The enteropathy which may accompany dermatitis herpetiformis resembles in many respects idiopathic steatorrhoea (Fry et al., 1967), and it has been suggested that the enteropathy is due to gluten sensitivity and that the skin lesions are related to the enteropathy (Fry et al., 1968). However, about $30 \%$ of patients with dermatitis herpetiformis have no small-intestinal abnormality, and in Case 2 the enteropathy was controlled on a gluten-free diet when the skin eruption appeared, thus making gluten sensitivity an unlikely cause of the rash.

A "secondary coeliac syndrome" identical to idiopathic steatorrhoea may occur in a number of disease states (Hindle and Creamer, 1965). Small-intestinal abnormalities remain, however, in dermatitis herpetiformis despite control of the rash with dapsone, and in Cases 1 and 2 the enteropathy preceded the skin eruption by eight and three years respectively.

Mature healthy adult relatives of children with coeliac disease may have partial or subtotal villous atrophy of the jejunal mucosa (MacDonald et al., 1965). An association, therefore, between this "potential coeliac disease" and dermatitis herpetiformis could explain the high incidence of jejunal abnormalities but low incidence of malabsorption syndrome in this skin disease. Also, partial villous atrophy has been reported in relatives of patients with dermatitis herpetiformis (Shuster et al., 1968).

At all events, just as dermatologists must exclude malabsorption in their patients with dermatitis herpetiformis, so physicians must consider dermatitis herpetiformis when an itching papulovesicular eruption occurs in idiopathic steatorrhoea.

We thank Professor A. S. Douglas and Dr. T. A. H. Pasieczny for permission to publish Case 1 and Professor T. D. V. Lawrie and Dr. J. O'D. Alexander for permission to publish Case 2. We are also grateful to Professor E. M. McGirr for his helpful criticism of this paper.

\section{REFERENCES}

Fraser, N. G., Murray, D., and Alexander, J. O'D. (1967). Brit. F. Derm., 79. 509.

Fry, L., Kier, P., McMinn, R. M. H., Cowan, J. D., and Hoffbrand, A. V. (1967). Lancet, 2, 729. Fry, L., McMinn, R. M. H., Cowan, J. D., and Hoffbrand, A. V. (1968).

Hindle, W.. and Creamer, B. (1965). Brit. med. 7., 2, 455.

MacDonald, W. C., Dobbins, W. O., and Rubin, C. E. (1965). New Engl. f. Med., 272, 448.

Marks, J., Shuster, S., and Watson, A. J. (1966). Lancet, 2, 1280.

Marks, R., Whittle, M. W., Beard, R. J., Robertson, W. B., and Gold S. C. (1968). Brit. med. f., 1, 552.

Shuster, S., Watson, A. J., and Marks, J. (1968). Lancet, 1, 1101.

van Tongeren, J. H. M., van der Staak, W. J. B. M., and Schillings, P. H. M. (1967). Lancet, 1, 218. 